\title{
Renal involvement in rheumatoid arthritis
}

\section{Choroba nerek u chorych na reumatoidalne zapalenie stawów}

\author{
Anna Raczkiewicz, Zbigniew Nowak, Witold Tłustochowicz \\ Department of Internal Medicine and Rheumatology, Military Institute of Medicine in Warsaw, Poland
}

Key words: atherosclerosis, rheumatoid arthritis, renal disease.

Słowa kluczowe: miażdżyca, reumatoidalne zapalenie stawów, choroba nerek.

\begin{abstract}
Sum mary
Renal involvement is still a significant problem in rheumatoid arthritis (RA) patients. Reduced kidney function is detected in 5-50\% of them and is more prevalent than in the general population. During the last decades the picture of renal disease has changed due to earlier and more aggressive therapy of arthritis. Nephrotoxic drugs are withdrawn or used very rarely. Because of successful reduction of the inflammatory process, amyloidosis has become rare, as have other severe complications of active disease such as vasculitis. Acute renal failure is now very infrequent, but chronic kidney disease (CKD) still makes an important contribution to morbidity and mortality. Recent studies are focused on the association between CKD and chronic cardiovascular disease (CVD). The relation appears comparable to the association observed in diabetes mellitus. In the article we summarize the results of studies on renal disease in RA, including histopathology, risk factors and markers of renal involvement.
\end{abstract}

A range of renal disorders were described in rheumatoid arthritis (RA) patients several decades ago. There were numerous potential causes of nephropathy in RA: nephrotoxicity of disease-modifying antirheumatic drugs (DMARDs), non-steroid anti-inflammatory (NSAID) and analgesic drugs, secondary disease induced by chronic inflammation (especially amyloidosis) and renal manifestations linked to the primary disease process (predominantly mesangial glomerulonephritis). Nowadays many of the nephrotoxic drugs such as d-penicillamine and gold are no longer or very rarely used. NSAIDs are less frequently prescribed in high doses and are used for shorter periods. Amyloidosis has probably become rare as the

\section{Streszczenie}

Choroba nerek nadal stanowi istotny problem $u$ chorych na reumatoidalne zapalenie stawów (RZS). Ograniczoną funkcję nerek stwierdza się u 5-50\% chorych i występuje ona częściej niż w populacji ogólnej. W ciągu ostatnich dziesięcioleci obraz choroby nerek zmienit się dzięki stosowaniu wcześniejszego i bardziej agresywnego leczenia choroby podstawowej. Leki o działaniu nefrotoksycznym są wycofane lub rzadko używane. Dzięki skutecznemu zahamowaniu procesu zapalnego częstość występowania amyloidozy jest mniejsza, jak również rzadko obserwuje się inne ciężkie powikłania aktywnej choroby, takie jak zapalenie naczyń. Ostra niewydolność nerek występuje obecnie bardzo rzadko, jednak przewlekła choroba nerek nadal jest przyczyną zwiększonej chorobowości i śmiertelności. Badania z ostatnich lat koncentrują się na zależności przewlekłej choroby nerek i przewlekłych chorób sercowo-naczyniowych. Zależność ta wydaje się porównywalna do obserwowanej u chorych na cukrzycę. W artykule przedstawiono wyniki badań dotyczących powikłań nerkowych u chorych na RZS z uwzględnieniem wyników badań histopatologicznych, czynników ryzyka i wskaźników uszkodzenia nerek.

earlier interventional approach has prevented long-term uncontrolled disease activity. However, renal involvement in RA continues to be one of the important causes of morbidity and mortality next to cardiovascular disease and infections [1, 2]. It is difficult to evaluate the prevalence of renal involvement precisely because of the wide variety of diagnostic methods and different groups of examined patients. Reduced kidney function is detected in 5-50\% of RA patients, and it is more prevalent than in non-RA individuals [3]. It can be partially due to comorbidities, such as diabetes, hypertension and atherosclerosis, which are more frequent than in the general population, and partially due to RA treatment or the disease itself $[4,5]$.

Address for correspondence:

Anna Maria Raczkiewicz, MD, PhD, Department of Internal Medicine and Rheumatology, Military Institute of Medicine, Szaserów 128, 04-141 Warsaw, 44, e-mail: anna.raczkiewicz@gmail.com

Submitted: 13.05 .2014 
In this article we review literature studies on renal involvement in RA with the emphasis on articles published during the last 10 years.

\section{Histopathological studies}

A lot of earlier studies were based on histopathological findings from biopsies or necropsies. Boers et al. [6] in 1987 described renal abnormalities in 132 necropsied RA cases and found nephrosclerosis in 90\%, non-specific tubular changes in $41 \%$, vasculitis with renal involvement in $8 \%$, amyloidosis in 11\%, membranous glomerulopathy in $8 \%$ (all associated with gold or d-penicillamine treatment) and focal glomerular disease in $8 \%$ of samples. Severity of nephrosclerosis was positively related to age, RA duration and occurrence of hypertension, atherosclerosis and/or diabetes. Only 52\% of the patients had clinically recognized renal disease before death. Makino et al. [7] reported an analysis of renal biopsy specimens from 100 RA patients with mean disease duration of ten years. The urinalysis of these patients revealed: proteinuria with hematuria (50\%), proteinuria only (34\%) and hematuria only (11\%). Membranous glomerulopathy (MG) was the most common histological finding (31\%) and it was mostly associated with gold, d-penicillamine and bucillamine treatment, but the etiology of 5 cases was unclear. Mesangial proliferative glomerulonephritis (GN) was found in 21\% (including IgA nephropathy in 12\%), amyloidosis in $11 \%$, interstitial nephritis in $9 \%$ (half of the cases correlated with NSAIDs usage, and the remainder were associated with overlap systemic lupus erythematosus and Sjögren syndrome), sclerotic GN in $4 \%$ and crescentic GN in $2 \%$. As many as $22 \%$ of the patients showed tubulointerstitial changes (tubular atrophy, cell infiltration and fibrosis) and those lesions were more prevalent in patients with long disease duration.

In other studies the most common renal histology finding was mesangial proliferative $\mathrm{GN}$, and it was considered to be an extra-articular manifestation of RA [8]. Nevertheless, the frequency of that pathology was shown not to be higher than in non-RA patients [9]. Korpela et al. [10] studied mesangial immunofluorescence findings in 37 RA patients with hematuria and/or proteinuria and found a significant correlation between intensity of IgM deposits and serum level of IgM rheumatoid factor. The postulated role of IgA rheumatic factor in IgA nephropathy was not confirmed, but mesangial deposition of IgA correlated with serum IgA level and RA duration. Serum IgM and IgA were higher in patients with mesangial glomerulopathy and amyloidosis.

In a retrospective study by Helin et al. [11], 110 RA patients with clinical renal disease underwent renal biopsy. The predominant histopathology finding was mesangial
GN (36\%), followed by amyloidosis (30\%), membranous nephropathy (17\%), focal proliferative GN (4\%), minimal change nephropathy (3\%) and acute interstitial nephritis (1\%). Mesangial GN was frequently characterized by hematuria and deposition of IgM-containing immune complexes. Amyloidosis was the most frequent finding in patients with nephrotic syndrome, while proteinuria without nephritic syndrome was found in patients with amyloidosis, membranous and mesangial GN in almost equal quantities. Aggarval et al. [1] compared serum and urine abnormalities and results of renal biopsy in two groups of patients: with shorter ( $2-5$ years) and longer (> 5 years) RA duration. They concluded that renal dysfunction increases with duration and severity of RA.

The prevalence of secondary AA amyloidosis in histological studies was estimated to be between 5.8 and $30 \%$ depending on the patient population and method of assessment [12, 13].

Kuroda et al. [14] tested 1006 consecutive RA patients for the presence of amyloidosis in gastrointestinal biopsy performed between 1988 and 1997. The tests for amyloid deposits were positive in $7.1 \%$ of patients. The majority of them revealed urinary abnormalities, and renal biopsy confirmed amyloidosis in $91 \%$ of cases. Abdominal fat biopsy showed less specificity. In an Indian study of 113 RA patients with disease duration $>5$ years the prevalence of amyloidosis evaluated by positive abdominal fat biopsy and the presence of urinary abnormalities was approximately 7\% [15]. In 121 consecutive Polish RA patients Wiland et al. [16] found amyloid fat deposits in $29 \%$ of patients; $34 \%$ of them $(10 \%$ of the whole group) suffered from renal involvement. The amount of amyloid deposition in renal tissue correlated with renal impairment [17], while a lack of amyloid deposition in the glomeruli characterized patients with stable renal function [18].

There are no data about the length of the preclinical stage of amyloidosis. It is possible that nowadays it takes longer to develop clinical signs of renal amyloidosis than decades ago. The median time from the onset of arthritis to the clinically detected amyloidosis increased from 16 years in the 1960s to 19 years in the 1990s [19]. In an observational study with a mean follow-up of 4 (1-14) years, amyloidosis diagnosed by abdominal fat biopsy remained subclinical in $73 \%$ of patients [20]. Koivuniemi et al. [13] described autopsies of 369 RA patients who died between 1952 and 1991 and found amyloidosis in $30 \%$ of cases. Only half of those patients experienced proteinuria, and $37 \%$ of them were diagnosed with amyloidosis during life. It is possible that patients with amyloidosis die of other causes during that subclinical period, and therefore amyloidosis is more frequently detected in necropsies. 
Small vessel vasculitis is a rare (1-5\% of RA) severe complication of active RA, and it may affect the kidneys in approximately one quarter of vasculitis cases [22]. It may cause a necrotizing immune complex GN that requires intense immunosuppression [21]. Rheumatoid vasculitis has been decreasing over the last decades, possibly as a consequence of the more aggressive treatment of the disease.

\section{Prevalence and risk factors of renal involvement in rheumatoid arthritis - laboratory findings}

Despite many potential causes of renal disease in RA patients, data about the prevalence of renal disorders are limited. In a prospective study of 235 patients with early RA followed up for 42 months, the percentage of patients with proteinuria, hematuria and elevated serum creatinine increased during the time of the study [23]. Persistent proteinuria developed in $7 \%$ of patients; it was mostly drug-related (gold, d-penicillamine, bucillamine and, surprisingly, sulfasalazine and diclofenac) and reversible after discontinuation of the treatment. The frequency of intermittent or persistent microhematuria rose from $17 \%$ to $42 \%$ during the study and had no correlation with drug therapy. Elevation of serum creatinine was observed in $6 \%$ of patients during the time of the study. Older age (> 50) was a risk factor for hematuria and drug-related proteinuria. Higher C-reactive protein (CRP) and erythrocyte sedimentation rate (ESR) at the study entry were associated with development of drug-induced proteinuria. NSAIDs were found to play a role in renal dysfunction in patients on diuretics or with dehydration [23]

In a 10-year observational study of early RA in 168 patients there were only 5 cases with serious renal involvement - amyloidosis in 3 and GN in 2 patients [24]. In a retrospective study from the Rochester Epidemiology Project, the data of 609 RA patients followed up from 1955 to 2000 (median 12 years) were analyzed in terms of extra-articular lesions. Only 4 patients were diagnosed with GN (30-year cumulative incidence of 1.5\%) and 3 (cumulative incidence of $0.9 \%$ ) with amyloidosis [25]. Nevertheless, these studies were not designed to detect milder renal abnormalities.

Karstila et al. [26] observed 103 patients with RA nephropathy and 102 RA patients without nephropathy (all with long-standing RA) matched for age, gender and disease duration. After a median of 13 years (between 1988 and 2003) chronic renal failure (defined as serum creatinine $\geq 100 \mu \mathrm{mol} / \mathrm{l}$ in women and $115 \mu \mathrm{mol} / \mathrm{l}$ in men) was present in 38\% of the original nephropathy group and in $13.7 \%$ of controls. High creatinine levels ( $>200 \mu \mathrm{mol} / \mathrm{l}$ ) were most frequently found in patients with combined proteinuria and hematuria (57\%), then in patients with isolated proteinuria (30\%), only in $8 \%$ of patients with isolated hematuria and in none with chronic renal disease without urinary abnormalities. Probable or definite amyloidosis was diagnosed in 19\% of patients in the nephropathy group and in $4 \%$ of patients in the control group. The patients who had been on azathioprine treatment were more likely to develop amyloidosis. Dialysis therapy was given to about $10 \%$ of patients in the nephropathy group and $2 \%$ of patients in the control group. There were six renal deaths, all in the original nephropathy group. New renal abnormalities, mostly mild, were detected in $28 \%$ of patients in the control group. The authors concluded that the course of the first 10-15 years of RA had determined the risk of development of renal complications. The study started in 1988; therefore the authors used creatinine serum concentration instead of estimated glomerular filtration rate (GFR), so the prevalence of renal dysfunction was probably underestimated.

In 1999 Sivhonen et al. [27] studied the relationship between RA nephropathy and mortality. In the group of 604 RA patients originally screened in 1988, isolated proteinuria was present in $4.5 \%$, isolated hematuria in $9 \%$, combined hematuria and proteinuria in $1.2 \%$, microalbuminuria in $5.6 \%$ and chronic renal failure in $5.8 \%$ of patients. All the signs of nephropathy except for isolated hematuria were associated with increased mortality.

In the more recent Methotrexate and Renal Insufficiency (MATRIX) study, the prevalence of kidney disease was evaluated in 129 consecutive RA patients. Using the Modification of Diet in Renal Disease (MDRD) and the Cockcroft-Gault (CG) formulas, the authors found kidney disease in $46.3 \%$ (MDRD) to $57 \%$ (CG) of patients. Among these, 20\% were in stage 2 and 15\% (MDRD) to $24.1 \%$ (CG) were in stage 3 of chronic kidney disease according to the National Kidney Foundation (NKF). Proteinuria was detected in 16\%, hematuria in 17\% and uninfectious leucocyturia in $20 \%$ of patients [4].

In another recent study performed in England, 350 consecutive RA patients were assessed for the presence of renal involvement risk factors. Fifty-three percent of them had mild renal impairment (GFR 60 to $90 \mathrm{ml}$ $\mathrm{min} / 1.73 \mathrm{~m}^{2}$ ), and $13 \%$ had moderate renal impairment with GFR less than $60 \mathrm{ml} / \mathrm{min} / 1.73 \mathrm{~m}^{2}$. There were significant associations between GFR and age, RA duration, systolic blood pressure, total cholesterol, triglycerides, insulin resistance and serum uric acid. Uric acid had the most powerful association with renal dysfunction, but only in patients with renal impairment $(r=-0.45)$. There was no association of renal involvement with disease activity and use of anti-inflammatory drugs or DMARDs (in that study mostly methotrexate). The authors sug- 
gest that serial measurements of serum uric acid concentration could serve as a marker of early GFR changes in RA patients [28]. The suggestions from that study have been confirmed by other authors.

In 2010 Daoussis et al. [29] analyzed 400 consecutive RA patients in terms of the relation between renal function and the signs of metabolic syndrome: hypertension, hyperlipidemia, obesity and insulin resistance. There were 220 (55\%) patients with GFR between 60 and $90 \mathrm{ml} / \mathrm{min} / 1.73 \mathrm{~m}^{2}, 47$ (11.5\%) patients with GFR less than 60 , and only 4 (1\%) patients with severe renal impairment (GFR < 30). The researchers found that GFR deterioration was strongly associated with age, disease duration and extra-articular disease manifestations (except for nodules and sicca syndrome). A strong negative correlation of GFR with hypertension, lipid profile (total cholesterol and triglycerides), insulin resistance and serum uric acid was also observed. Moreover, chronic cardiovascular disease (CVD) defined as the presence of coronary heart disease, cerebrovascular accident or peripheral vascular disease was negatively correlated with GFR. There was no significant association between disease activity, inflammatory markers, RA treatment and GFR. Similar results have been obtained by Haroon et al [30], who found a statistically significant correlation between disease duration, presence of CVD, high CRP and chronic kidney disease (CKD). The association between CVD and CKD remained significant after adjusting for age, gender, duration of arthritis and CRP.

In the ongoing prospective cohort CARRÉ study, the patients who experienced CV events had significantly lower GFR than other RA patients. The authors calculated that the decrease in estimated GFR (MDRD) of $5 \mathrm{ml}$ min portends a yearly increase of CVD risk of $11 \%$. Additional adjustment for age, gender, traditional CV risk factors and RA-related factors did not change the association. The relationship was stronger than in the general population and similar to the association observed in diabetes mellitus [31]. In 813 patients with RA and 813 non-RA individuals (mean age $56 \pm 16$ years) the 20 -year cumulative incidence of reduced kidney function was higher in patients with RA compared with non-RA participants ( $25 \%$ vs. $20 \%, p=0.03)$. The presence of CVD at baseline and elevated erythrocyte sedimentation rate in patients with RA was associated with increased risk of eGFR $<60 \mathrm{ml} / \mathrm{min} / 1.73 \mathrm{~m}^{2}$, and conversely a deeper reduction in GFR (eGFR $<45 \mathrm{ml} / \mathrm{min} / 1.73 \mathrm{~m}^{2}$ ) was associated with increased risk of CVD [3].

\section{Markers of renal involvement}

Kidney injury may not be apparent in terms of signs and symptoms, so functional parameters are used to detect it. Serum creatinine is the most commonly used parameter for renal excretory function. The estimated GFR defines the stage of CKD [32]. Unfortunately, the MDRD and CG formulas used for GFR prediction may underestimate renal function in RA patients [33]. This is attributed to loss of muscle mass and because of it creatinine production [34]. The concentration of serum cystatin C is mainly determined by GFR and is independent of age, gender and muscle mass; therefore some authors tried to use serum cystatin C measurements. It worked better than serum creatinine [35] but worse than MDRD and CG formulas as an indicator of renal failure in RA [36]. Urinalysis is the other routinely performed screening examination. The presence of proteinuria and/or hematuria may indicate nephropathy regardless of GFR. Proteinuria may originate from glomerular or tubulointerstitial damage; it can also be caused by overflow of serum proteins, so it is important to distinguish albumin secretion (glomerular disease) from other proteins (protein overflow or tubular disease). Formerly the 24-hour urine collection had been performed for assessment of the quantity of proteinuria, but the urinary protein/creatinine ratio or albumin/creatinine ratio is more suitable and nowadays more often used in practice [22].

In 1999 Niederstadt et al. [37] examined the prevalence of nephropathy in 44 consecutive RA (patients with amyloidosis excluded) and 46 osteoarthritis (OA) patients by measurement of marker proteins for glomerular (albumin and immunoglobulin G) and tubular damage ( $\alpha 1$-microglobulin) in 24-hour urine samples. Pathological proteinuria (defined as urine albumin $>25 \mathrm{mg} / \mathrm{l}$ and $\alpha 1$-microglobulin > $14 \mathrm{mg} / \mathrm{l}$ ) was found in 24 (55\%) RA patients, and the possible cause (such as nephrotoxic drugs) was not identified in $75 \%$ of them. Tubular proteinuria occurred in 15 (36\%) of patients. Impaired renal function was seen in only two patients.

The other markers of renal damage that had been studied in RA patients were: N-acetyl-glucosaminidase (NAG) and $\beta 2$-microglobulin. $\mathrm{N}$-acetyl-glucosaminidase is a simple and sensitive test of tubular damage used as an early sign of renal graft rejection. In two earlier studies, an abnormally raised urinary NAG was detected in 8 of 20 untreated RA patients and rising of NAG excretion was correlated with disease activity, suggesting that the inflammatory process affects renal function [38]. Wiland et al. [39] described a decrease in the incidence (from $71.4 \%$ to $47.6 \%$ of patients) of elevated NAG values in RA patients in the course of low-dose methotrexate treatment, which can be attributable to reduction of inflammation. In a quite recent study on 35 untreated early RA patients and 35 non-RA controls, the authors found NAG enzymuria in 13 and microalbuminuria in 4 RA patients, and concluded that NAG is a sensitive marker of asymp- 
tomatic renal lesions in early RA [40]. Beta-2-microglobulin is a marker of renal proximal tubular dysfunction. Viergever et al. [41] found elevation of $\beta 2$-microglobulin serum concentration in $44 \%$ and urine excretion in $19 \%$ of 101 RA patients. This correlated with a more severe RA and the presence of extra-articular disease manifestation.

The presence of microalbuminuria (MA) in RA patients has been investigated in a number of studies. Most of them suggest that MA is relatively common in RA patients; however, the implication of this phenomenon is still a matter of debate.

In two studies conducted 18 and 17 years ago, this abnormality was found in $27.7 \%$ of RA patients (after excluding those with previous renal disease, diabetes and hypertension) [42, 43]. Most of the cases were probably due to gold and d-penicillamine treatment. Mpofu et al. [44] in 2004 described MA in only $7.7 \%$ of RA patients (similarly: renal disease, diabetes and hypertension excluded). The results were comparable to control groups reported in other MA studies, but the majority of the patients were on effective methotrexate treatment. A study done in 2002 found a prevalence of $30 \%$ compared to $5 \%$ of controls [45].

In a recent study, Verma et al. [46] compared 100 RA patients (the same exclusion criteria as mentioned above) with 100 gender- and age-matched controls. The relative frequency of MA was $26 \%$ vs. $4 \%$, and the median frequency of MA was significantly greater than in controls.

Microalbuminuria significantly correlated with indices of inflammation, disease duration and number of joints involved. The authors suggest that urinary albumin excretion reflects a systemic reaction in the acute phase response. Unfortunately, the authors did not provide detailed information about ongoing RA treatment. Another study conducted by Daoussis et al. [47] was designed to assess factors associated with MA, especially CVD and metabolic syndrome. The study comprised 337 consecutive RA patients, most of them on DMARD treatment. Methotrexate was the most widely used drug (57.9\%), followed by sulfasalazine (29.4\%). Only 2 patients were taking cyclosporine, and there were no patients on gold or d-penicillamine. The majority of patients (70\%) suffered from hypertension, and 9.2\% were diabetic. Taking into account these factors, MA was detected in a small part (11.9\%) of the whole group and in $3.1 \%$ of non-diabetic and non-hypertensive patients. Renal function was not significantly different between normoalbuminuric and microalbuminuric patients. Hypertension, insulin resistance and diabetes were more prevalent among albuminuric patients. In a multivariable analysis, MA patients had twofold increased likeli- hood of having metabolic syndrome after adjusting for age and gender. There was no association with disease activity and treatment. In a cross-sectional study aimed at evaluating organ damage associated with cardiovascular risk in RA patients without CVD diagnosis, Panoulas et al. [48] found MA in 12\% of 251 patients. There were significant associations with age, hypertension and diabetes but not with RA treatment. The authors suggest an association between tumor necrosis factor $\alpha$ (TNF- $\alpha$ ) secretion and organ damage (heart, kidney) on the basis of a population-based study. In the aforementioned study conducted by Sihvonen et al. [27], microalbuminuria predicted increased mortality in RA patients with a hazard ratio of 2.77 . The majority of microalbuminuric patients (63\%) died of cardiovascular disease, and only a small minority had amyloidosis.

\section{Rheumatoid arthritis treatment and renal involvement}

Treatment strategies in RA have significantly changed in the past decade. The usage of strictly nephrotoxic drugs is limited. Early and aggressive therapeutic intervention results in better outcomes. Recent studies mentioned above showed that kidney damage in RA patients is nowadays mostly associated with age, disease duration (persistent inflammation) and comorbidities (hypertension, diabetes) leading to premature atherosclerosis. It seems that aggressive RA treatment should prevent not only joint damage but also kidney impairment.

On the other hand, it is reported that $18 \%$ of rheumatology clinic patients have a GFR of $60 \mathrm{ml} / \mathrm{min}$ or less, and it is likely that some patients with RA will have concomitant renal involvement [22]. Such individuals should be regarded as high risk for cardiovascular complications. Several drugs cannot be used in CKD patients or should be used in caution.

NSAIDs are drugs which can cause deterioration of kidney function, particularly in older patients, those with CKD (especially diabetic and hypertension nephropathy) and/or heart failure. NSAID-induced nephrotoxicity includes acute tubular necrosis, acute tubulointerstitial nephritis, glomerulonephritis, renal papillary necrosis, salt and water retention, hypertension, hyperkalemia and hyporeninaemic hypoaldosteronism [49]. Nevertheless, literature data on NSAID usage in RA patients demonstrated that this treatment appeared quite safe, but the number and quality of studies are limited. In a Cochrane review [50] performed in 2010, there were 17 studies which included RA patients using methotrexate with various NSAIDs, assessed in terms of adverse effects. In only one study was the long-term effect of NSAIDs on 
renal function assessed, and no significant renal impairment was found. Another study demonstrated that a $2 \mathrm{~g}$ daily dose of aspirin induced partially reversible renal impairment [51]. The authors of the review concluded that NSAID use with methotrexate appeared to be safe provided appropriate monitoring had been performed. In a retrospective study on 99 RA patients, Pathan et al. [49] found $27.7 \%$ incidence of reversible renal insufficiency during a two-year follow-up of NSAID treatment. Interestingly, a recent national cohort study in Danish RA patients showed that cardiovascular risk associated with NSAID use was significantly lower than in non-RA individuals [52].

Cyclosporine A (CSA) is another potentially nephrotoxic drug. Cyclosporine A causes vasoconstriction of glomerular arterioles and, as a result, a reduction in renal blood flow and GFR. Prolonged therapy can cause obliterative arteriolopathy, tubular atrophy and progressive renal impairment [22]. Cyclosporine A is contraindicated in RA patients with renal dysfunction. In the European League Against Rheumatism (EULAR) 2013 recommendations, CSA can be used only in rare, exceptional situations in RA patients [53].

Methotrexate (MTX) is commonly used as a firstline agent in RA treatment. About $90 \%$ of the absorbed MTX is excreted unchanged by glomerular filtration and proximal tubular excretion. Direct renal toxicity of MTX occurs very rarely, but diminished excretion due to renal failure increases the risk of non-renal toxicity, mostly bone marrow suppression [4]. The elimination half-life of MTX rises from 3-8 $\mathrm{h}$ in patients with normal renal function to as long as $120 \mathrm{~h}$ in patients undergoing peritoneal dialysis. The use of MTX in such patients, even at very low doses ( $2.5 \mathrm{mg}$ weekly), may have severe consequences. There are several case reports about pancytopenia in patients on low-dose methotrexate and hemodialysis; some of them died [54]. Methotrexate is not recommended in patients with GFR $<15 \mathrm{ml} / \mathrm{min} / 1.73 \mathrm{~m}^{2}$. In patients with GFR between 15 and $60 \mathrm{ml} / \mathrm{min} / 1.73 \mathrm{~m}^{2}$ the initial dose range is $2.5-7.5 \mathrm{mg}$ once a week and may be increased up to half of the maximal dose [4].

Antimalarial drugs and sulfasalazine are only partially excreted by the kidneys, and dose reduction is needed at GFR $<50 \mathrm{ml} / \mathrm{min} / 1.73 \mathrm{~m}^{2}$ [22].

Tumor necrosis factor $\alpha$ blockers appear to be safe in patients with renal impairment and may be an alternative treatment option in patients with end-stage renal disease on hemodialysis. Their metabolism seems not to be influenced by renal function [55]. There are some case reports about successful treatment of arthritis in patients undergoing hemodialysis with infliximab, etanercept and adalimumab, but the data about efficacy and safety are limited $[54,56]$. Additionally there are some reports about the efficacy of TNF antagonists in renal amyloidosis. Treatment of 14 patients with AA amyloidosis with etanercept resulted in a decrease of proteinuria and improvement of serum albumin concentration accompanied by a fall of serum amyloid $A$ levels [57]. In 4 patients treated with infliximab and concomitant MTX, creatine clearance did not change significantly over 8 years, and progressive decline of proteinuria was observed [58]. On the other hand, there are rare cases of TNF antagonists causing GN, sometimes with acute renal insufficiency $[59,60]$.

\section{Conclusions}

The modern treatment approach helps to avoid serious renal complications in the majority of RA patients, but despite changes in treatment strategies and development of new DMARDs, renal disease is still more prevalent in RA than in the general population. The picture of renal involvement in RA evolved to a more chronic process, associated mostly with cardiovascular risk factors and persistent inflammation.

Rheumatoid arthritis patients should be routinely monitored for the presence of renal disease. If persistent urine abnormalities are found, the patient should be referred to a nephrologist for further diagnosis. Rheumatologists should be aware of concomitant CKD in RA patients and adjust therapeutic methods to renal function. We should take special care of NSAID users in older age and patients with coexisting diabetes, hypertension or heart disease, because they are the most exposed to NSAID nephrotoxicity.

The authors declare no conflict of interest.

\section{References}

1. Aggarval HK, Singh $\mathrm{H}$, Jain $\mathrm{D}$, et al. Histofunctional status of kidney in patients with rheumatoid arthritis. Dicle Med J 2011; 38: 375-381.

2. Kaplan MJ. Cardiovascular complications of rheumatoid arthritis-assessment, prevention and treatment. Rheum Dis Clin North Am 2010; 36: 405-426.

3. Hickson LJ, Crowson CS, Gabriel SE, et al. Development of reduced kidney function in rheumatoid arthritis. Am J Kidney Dis 2013; 63: 206-213.

4. Karie S, Gandjbakhch F, Janus N, et al. Kidney disease in RA patients: prevalence and implication on RA-related drugs management: the MATRIX study. Rheumatology (Oxford) 2008; 47: 350-354.

5. Loza E, Jover JA, Rodriguez-Rodriguez L, Carmona L. Observed and expected frequency of comorbid chronic diseases in rheumatic patients. Ann Rheum Dis 2008; 67: 418-421.

6. Boers M, Croonen AM, Dijkmans BA, et al. Renal findings in rheumatoid arthritis: clinical aspects of 132 necropsies. Ann Rheum Dis 1987; 46: 658-663. 
7. Makino H, Yoshinaga Y, Yamasaki Y, et al. Renal involvement in rheumatoid arthritis: analysis of renal biopsy specimens from 100 patients. Mod Rheumatol 2002; 12: 148-154.

8. Helin H, Korpela M, Mustonen J, Pasternack A. Mild mesangial glomerulopathy: a frequent finding in rheumatoid arthritis patients with hematuria or proteinuria. Nephron 1986; 42: 224-230.

9. Nakano M, Ueno M, Nishi S, et al. Determination of IgA ad IgM rheumatic factors in patients with rheumatoid arthritis with and without nephropathy. Ann Rheum Dis 1996; 55: 520-524.

10. Korpela M, Mustonen J, Teppo AM, et al. Mesangial glomerulonephritis as an extra-articular manifestation of rheumatoid arthritis. Br J Rheumatol 1997; 36: 1189-1195.

11. Helin HJ, Korpela MM, Mustonen JT, Pasternack Al. Renal biopsy findings and clinopathologic correlations in rheumatoid arthritis. Arthritis Rheum 1995; 38: 242-247.

12. Kronbichler A, Mayer G. Renal involvement in autoimmune connective tissue diseases. BMC Med 2013; 11: 95.

13. Koivuniemi R, Paimela L, Suomalainen R, et al. Amyloidosis is frequently undetected in patients with rheumatoid arthritis. Amyloid 2008; 15: 262-268.

14. Kuroda T, Tanabe N, Sakatsume M, et al. Comparison of gastroduodenal, renal and abdominal fat biopsies for diagnosing amyloidosis in rheumatoid arthritis. Clin Rhematol 2002; 21: 123-128.

15. Wakhlu A, Krisnani N, Hissaria P, et al. Prevalence of secondary amyloidosis in Asian North Indian patients with rheumatoid arthritis. J Rheumatol 2003; 30: 948-951.

16. Wiland P, Wojtała R, Goodacre J. The prevalence of subclinical amyloidosis in Polish patients with rheumatoid arthritis. Clin Rheum 2004; 23: 193-198.

17. Kuroda T, Tanabe N, Kobayashi D, et al. Significant association between renal function and area of amyloid deposition in kidney biopsy specimens in reactive amyloidosis associated with rheumatoid arthritis. Rheumatol Int 2012; 32: 3155-3162.

18. Uda H, Yokota A, Kobayashi K, et al. Two distinct clinical courses of renal involvement in rheumatoid patients with AA amyloidosis. J Rheumatol 2006; 33: 1482-1487.

19. Hazenberg BP, van Rijswijk MH. Where has secondary amyloid gone? Ann Rheum Dis 2000; 59: 577-579.

20. Gómez-Casanovas E, Sanmartí R, Solé $M$, et al. The clinica significance of amyloid fat deposits in rheumatoid arthritis: a systematic long-term followup study using abdominal fat aspiration. Arthritis Rheum 2001; 44: 66-72.

21. Genta M, Genta R, Gabay C. Systemic Rheumatoid vasculitis: a review. Semin Arthritis Rheum 2006; 36: 88-98.

22. Anders HJ, Vielhauer V. Renal co-morbidity in patients with rheumatic diseases. Arthritis Res Ther 2011; 13: 222.

23. Koseki Y, Terai C, Moriguchi M, et al. A prospective study of renal disease in patients with early rheumatoid arthritis. Ann Rheum Dis 2001; 60: 327-331.

24. Lindqvist E, Saxne T, Geborek P, Eberhardt K. Ten year outcome in a cohort of patients with early rheumatoid arthritis: health status, disease process and damage. Ann Rhem Dis 2002; 61 : 1055-1059.

25. Turesson C, O'Fallon WM, Crowson CS, et al. Extra-articular manifestations in rheumatoid arthritis: incidence trends and risk factors over 46 years. Ann Rheum Dis 2003; 62: 722-727.

26. Karstila K, Korpela M, Sihvonen S, Mustonen J. Prognosis of clinical renal disease and incidence of new renal findings in patients with rheumatoid arthritis: follow-up of the population-based study. Clin Rheumatol 2007; 26: 2089-2095.

27. Sihvonen S, Korpela M, Mustonen J, et al. Renal disease as a predictor of increased mortality among patients with rheumatoid arthritis. Nephron Clin Pract 2004; 96: c107-114.

28. Daoussis D, Panoulas V, Toms T, et al. Uric acid is a strong independent predictor of renal dysfunction in patients with rheumatoid arthritis. Arthritis Res Ther 2009; 11: R116.

29. Daoussis D, Panoulas VF, Antonopoulos I, et al. Cardiovascular risk factors and not disease activity, severity or therapy associate with renal dysfunction in patients with rheumatoid arthritis. Ann Rheum Dis 2010; 69: 517-521.

30. Haroon M, Adeeb F, Devlin J, et al. A comparative study of renal dysfunction in patients with inflammatory arthropathies: strong association with cardiovascular diseases and not with anti-rheumatic therapies, inflammatory markers or duration of arthritis. Int J Rheum Dis 2011; 14: 255-260.

31.van Sijl AM, van den Oever IA, Peters MJ, et al. Subclinical renal dysfunction is independently associated with cardiovascular events in rheumatoid arthritis: the CARRÉ study. Ann Rheum Dis 2012; 71: 341-344.

32. National Kidney Foundation. K/DOQI clinical practice guidelines for chronic kidney disease: evaluation, classification and stratification. Am J Kidney Dis 2002; 39 (2 Suppl 1): S1-S266.

33. Anders HJ, Rihl M, Vielhauer V, Schattenkirchner M. Prediction of creatinine clearance from serum creatinine in patients with rheumatoid arthritis: comparison of six formulae and one nomogram. Clin Rheumatol 2002; 8: 130-133.

34. Pathan E, Joshi VR. Rheumatoid arthritis and the kidney. J Assoc Physicians India 2004; 52: 488-494.

35. Mangge $\mathrm{H}$, Liebmann $\mathrm{P}$, Tanil $\mathrm{H}$, et al. Cystatin $\mathrm{C}$, an early indicator for incipient renal disease in rheumatoid arthritis. Clin Chim Acta 2000; 300: 195-202.

36. Karstila K, Harmoinen AP, Lehtimäki TJ, et al. Measurement of the kidney function in patients with rheumatoid arthritis: plasma cystatin C versus 51Cr-EDTA clearance. Nephron Clin Pract 2008; 108: c284-c290.

37. Niederstadt C, Happ T, Tatsis E, et al. Glomerular and tubular proteinuria as markers of nephropathy in rheumatoid arthritis. Rheumatology (Oxford) 1999; 38: 28-33.

38. Iqbal M, Waqar M, Mehboobali N, et al. Urinary N-acetyl-D-glucosamidase in rheumatoid arthritis. Exp Mol Med 1998; 30: 95-101.

39. Wiland P, Swierkot J, Szechiński J. N-acetyl-D-glucosamidase urinary excretion as an early indicator of kidney dysfunction in rheumatoid arthritis patients on low-dose methotrexate treatment. Br J Rheumatol 1997; 36: 59-63.

40.Spasovski D, Gruev T, Marina N, et al. The diagnostic value of $\mathrm{N}$-acetyl- $\beta$-D-glucosamidase and microalbumin concentration in rheumatoid arthritis. JMB 2007; 26: 300-308.

41. Viergever P, Swaak A. Urine and serum beta-2-microglobulin in patients with rheumatoid arthritis: a study of 101 patients without signs of kidney disease. Clin Rheum 1989; 8: 368-374.

42. Pedersen LM, Nordin H, Svensson B, Bliddal H. Microalbuminuria in patients with rheumatoid arthritis. Ann Rheum Dis 1995; 54: 189-192.

43. Nordin H, Pedersen LM, Svensson BH, Bliddal H. Microalbuminuria in rheumatoid arthritis. Ugersk Laeger 1996; 158: 31413143 [Abstract]. 
44. Mpofu S, Kaushik VV, Grundy G, Moots RJ. Microalbuminuria: is it a predictor of ischaemic heart disease in rheumatoid arthritis? Rheumatology (Oxford) 2004; 43: 537-538.

45. Bhatt G, Mathur D, Saxena G, et al. Micoralbuminuria in rheumatoid arthritis a correlation with disease activity. J Assoc Phys India 2002; 50: 82.

46. Verma M, Shanker V, Singh H, et al. Microalbuminuria: a mark er of severe disease activity in rheumatoid arthritis. Indian J Rheum 2013; 8: 112-116.

47. Daoussis D, Panoulas VF, John $\mathrm{H}$, et al. Microalbuminuria in rheumatoid arthritis in the post gold/penicillamine era: association with hypertension, but not therapy or inflammation. Clin Rheumatol 2011; 30: 477-484.

48. Panoulas VF, Toms TE, Metsios GS, et al. Target organ damage in patients with rheumatoid arthritis: The role of blood pressure and heart rate. Atherosclerosis 2010; 209: 255-260.

49. Pathan E, Gaitonde S, Rajadhyaksha S, et al. A longitudinal study of serum creatinine levels in patients of rheumatoid arthritis on long term NSAID therapy. J Assoc Physicians India 2003; 51: 1045-1049.

50. Colebatch AN, Marks JL, Edwards CJ. Safety of non-steroida anti-inflammatory drugs, including aspirin and paracetamol (acetaminophen) in people receiving methotrexate for inflammatory arthritis (rheumatoid arthritis, ankylosing spondylitis, psoriatic arthritis, other spondylitis). Cochrane Database Syst Rev 2011; 11: CD008872.

51. Seideman P, Müller-Suur R. Renal effects of aspirin and low dose methotrexate in rheumatoid arthritis. Ann Rheum Dis 1993; 52: 613-615.

52. Lindhardsen J, Gislason GH, Jacobsen S, et al. Non-steroida anti-inflammatory drugs and risk of cardiovascular disease in patients with rheumatoid arthritis: a nationwide cohort study. Ann Rheum Dis 2013. doi: 10.1136/annrheumdis-2012-203137.

53. Smolen JS, Landewé R, Breedveld FC, et al. EULAR recommendations for the management of rheumatoid arthritis with synthetic and biological disease- modifying antirheumatic drugs: 2013 update. Ann Rheum Dis 2014; 73: 492-509.

54. Al-Hasani H, Roussou E. Methotrexate for rheumatoid arthritis patients who are on hemodialysis. Rheumatol Int 2011; 31 1545-1547.

55.Don BR, Kim K, Li J, et al. The effect of etanercept on suppression of the systemic inflammatory response in chronic hemodialysis patients. Clin Nephrol 2010; 73: 431-438.

56. Senel S, Kisacik B, Ugan Y, et al. The efficacy and safety of etanercept in patients with rheumatoid arthritis and spondyloarthropathy on hemodialysis. Clin Rheumatol 2011; 30: 1369-1372.

57. Nakamura T, Higashi S, Tomoda K, et al. Etanercept can induce resolution of renal deterioration in patients with amyloid A amyloidosis secondary to rheumatoid arthritis. Clin Rheumatol 2010; 29: 1395-1401.

58. Keersmaekers T, Claes K, Kuypers DR, et al. Long-term efficacy of infliximab treatment for AA-amyloidosis secondary to chronic inflammatory arthritis. Ann Rheum Dis 2009; 68: 759-761.

59. Stokes MB, Foster K, Markowitz GS, et al. Development of glomerulonephritis during anti-TNF therapy for rheumatoid arthritis. Nephrol Dial Transplant 2005; 20: 1400-1406.
60. Chen TJ, Yang YF, Huang PH, et al. Permanent renal loss following tumor necrosis factor $\alpha$ antagonists for arthritis. Rheumatol Int 2010; 30: 1077-1079. 